\title{
Preplant and Postemergence Control of Glyphosate-Resistant Giant Ragweed in Corn
}

\author{
Kimberly D. Belfry*, Peter H. Sikkema \\ University of Guelph, Ridgetown Campus, Ridgetown, Canada \\ Email: *kimberly.belfry@gmail.com
}

Received 2 February 2015; accepted 24 February 2015; published 27 February 2015

Copyright (C) 2015 by authors and Scientific Research Publishing Inc.

This work is licensed under the Creative Commons Attribution International License (CC BY). http://creativecommons.org/licenses/by/4.0/

c) (i) Open Access

\begin{abstract}
Glyphosate-resistant (GR) giant ragweed has recently been identified in southwestern Ontario and has the potential to be a significant problem for regional corn producers. Eight field trials [four with preplant (PP) and four with postemergence (POST) herbicides] were conducted from 2013 to 2014 on various Ontario farms infested with GR giant ragweed to determine the efficacy of PP and POST tank-mixes in corn. Glyphosate tank-mixed with atrazine, dicamba, dicamba/atrazine, mesotrione plus atrazine, flumetsulam, isoxaflutole plus atrazine, saflufenacil/dimethenamid-P, $S$ metolachlor/atrazine and rimsulfuron applied PP provided up to $54 \%, 95 \%, 93 \%, 95 \%, 40 \%, 89 \%$, $91 \%, 50 \%$ and $93 \%$ control of GR giant ragweed and reduced dry weight $69 \%, 100 \%, 99 \%, 100 \%$, $30 \%, 92 \%, 98 \%, 66 \%$ and $99 \%$, respectively. POST application of glyphosate alone and tankmixed with 2,4-D ester, atrazine, dicamba, dicamba/diflufenzopyr, dicamba/atrazine, bromoxynil plus atrazine, prosulfuron plus dicamba, mesotrione plus atrazine, topramezone plus atrazine, tembotrione/thiencarbazone-methyl and glufosinate provided up to $31 \%, 84 \%, 39 \%, 94 \%, 89 \%$, $86 \%, 83 \%, 78 \%, 72 \%, 43 \%, 63 \%$ and $58 \%$ GR giant ragweed and reduced dry weight $55 \%, 99 \%$, $72 \%, 99 \%, 99 \%, 98 \%, 96 \%, 96 \%, 93 \%, 89 \%, 91 \%$ and $95 \%$, respectively. In general, PP control of GR giant ragweed was greater than POST applied herbicides evaluated. Based on these results, glyphosate tank-mixes containing dicamba or mesotrione plus atrazine applied PP, and dicamba applied POST will provide the most consistent control of GR giant ragweed in corn.
\end{abstract}

\section{Keywords}

Corn, Glyphosate-Resistant Giant Ragweed, Preplant Herbicide, Postemergence Herbicide

${ }^{*}$ Corresponding author. 


\section{Introduction}

Giant ragweed (Ambrosia trifida L.) is among the most competitive weeds for corn (Zea mays L.) producers in southwestern Ontario, Canada. Native to North America, this annual weed of the Asteraceae family has a pattern of early and prolonged emergence that makes control particularly difficult [1]. Giant ragweed has been traditionally found in low-lying undisturbed regions such as fencerows, drainage ditches and occasionally flood plains [2]. However, dispersal from its natural habitat has facilitated adaptation to fertile agricultural fields over the past two decades [3].

Giant ragweed is an aggressive agricultural weed that gains an early competitive advantage by germinating prior to other annual species [2]. Easily identified by its large spoon-shaped cotyledons, giant ragweed may germinate over a wide range of temperature and soil moisture conditions [1]. Once emerged, seedlings exhibit rapid growth and typically reach heights of at least one meter greater than surrounding crop plants [3]; increased growth can be attributed to a high photosynthetic rate as well as a large leaf area [4]. Giant ragweed's large stature results in the eventual suppression and elimination of surrounding plants through competition for water, nutrients and other habitat resources [1]. In soybean, yield loss of up to 50\% has been reported from as few as two plants per $9 \mathrm{~m}$ row [5]. A study on competition and fecundity of giant ragweed in corn determined that yield loss was greatest for crops in which the weeds emerged concurrently, relative to crops where giant ragweed emergence was four weeks subsequent [6]. They predicted that a single giant ragweed plant per $10 \mathrm{~m}^{-2}$ could depress corn yields by up to $14 \%$ and that a maximum of $90 \%$ loss was possible at high weed densities, when weed and crop emergence was simultaneous.

Giant ragweed is monoecious, having both male and female flowers present on individual plants [2]. Male flowers may be found on terminal racemes at the top of the plant with female flowers clustered at the base of each raceme [3]. Giant ragweed flowers from August to October in Ontario and the pollen is a major contributor of hay fever [7]. Due to the relative position of male and female flowers, pollen transfer is most often facilitated via wind. Consequently, giant ragweed populations typically possess a high degree of genetic variability that is attributed primarily to cross-pollination among neighboring plants. Heterogeneity within plant populations, specifically weeds, may better enable a species to buffer unfavorable changes including vulnerability to pathogenic, insect and environmental stresses and in turn potentially make control more difficult [8].

In 2008, a population of giant ragweed from a field near Windsor, Ontario was reported as not being controlled by a standard field application of glyphosate [9]. Subsequently, resistance to glyphosate was confirmed at 3 and 12 times the maximum recommended rate under greenhouse and field testing, respectively. In 2009 and 2010, a survey of southwestern Ontario confirmed GR giant ragweed populations in 47 additional locations indicating a greater distribution of resistant plants than originally anticipated [10]. By 2012, GR giant ragweed was further detected in four Ontario counties, with five populations demonstrating multiple resistances to both glyphosate and cloransulam-methyl [11]. In response to the discovery of GR giant ragweed in southwestern Ontario, affected growers have been forced to diversify management strategies in an effort to maintain control and prevent corn yield loss due to weedy infestations.

Since GR giant ragweed was first identified, there have been numerous studies conducted on the control and management of this troublesome weed [12]-[16]. Although efficacious weed control has been reported, much of the literature is concentrated on weed control in soybean and there is limited information regarding control in corn. The objectives of this study were to determine the efficacy of glyphosate tank-mixed with 2,4-D, atrazine, dicamba, dicamba/atrazine, mesotrione plus atrazine, flumetsulam, isoxaflutole plus atrazine, saflufenacil/dimethenamid-P, $S$-metolachlor/atrazine and rimsulfuron applied preplant (PP) and glyphosate alone and tank-mixed with 2,4-D ester, atrazine, dicamba, diflufenzopyr, dicamba/atrazine, bromoxynil plus atrazine, prosulfuron plus dicamba, mesotrione plus atrazine, topramezone plus atrazine, tembotrione/thiencarbazone-methyl and glufosinate applied postemergence (POST) for the control of GR giant ragweed in corn, under Ontario field conditions.

\section{Materials and Methods}

\subsection{Study Establishment}

Eight field trials were conducted in 2013 and 2014 on farms located near Tilbury, Essex and Harrow, Ontario, Canada, to evaluate the efficacy of PP and POST glyphosate tank-mixes for GR giant ragweed control in corn. Giant ragweed populations were confirmed as resistant to glyphosate prior to study establishment [10]. The first set of trials determined GR giant ragweed control using various PP tank-mixtures while the second examined GR 
giant ragweed control using POST tank-mixes. Each experiment was arranged as a randomized complete block design with four replications. Plots measured $2 \mathrm{~m}$ wide by $8 \mathrm{~m}$ long. For the "PP Tank-mixes" trial, herbicides were applied following GR giant ragweed emergence but prior to seeding of corn; for the "POST Tank-mixes", herbicides were applied following corn emergence. Applications were made using a $\mathrm{CO}_{2}$-pressurized backpack sprayer calibrated to deliver $200 \mathrm{~L}$ aqueous solution $\mathrm{ha}^{-1}$ at $240 \mathrm{kPa}$. Boom length was $1.5 \mathrm{~m}$ with four ultra-low drift nozzles (ULD 120-02, Hypro, New Brighton, MN) spaced $50 \mathrm{~cm}$ apart. A weedy and weed-free control was included in each replicate of each trial. Weed-free controls were sprayed prior to corn seeding with glyphosate $\left(1800 \mathrm{~g} \cdot \mathrm{ae} \cdot \mathrm{ha}^{-1}\right)$ and $2-4$, D ester $\left(500 \mathrm{~g} \cdot \mathrm{ae} \cdot \mathrm{ha}^{-1}\right)$ or glyphosate $\left(900 \mathrm{~g} \cdot \mathrm{ae} \cdot \mathrm{ha}^{-1}\right) \mathrm{plus}$ saflufenacil/dimethenamid-P (735 g ae $\left.\cdot \mathrm{ha}^{-1}\right)$ and maintained weed-free by hoeing and hand weeding as required throughout the growing season. Details of soil characteristics, herbicide application dates and GR giant ragweed density and height are listed in Table 1.

PP tank-mix treatments included glyphosate $\left(1800 \mathrm{~g} \cdot \mathrm{ae} \cdot \mathrm{ha}^{-1}\right)$ mixed with 2,4-D, atrazine, dicamba, dicam$\mathrm{ba} /$ atrazine, mesotrione plus atrazine, flumetsulam, isoxaflutole plus atrazine, saflufenacil/dimethenamid-P, $S$ metolachlor/atrazine and rimsulfuron. Herbicide doses are listed in Table 2. POST tank-mix treatments included glyphosate and glyphosate tank-mixed with 2,4-D ester, atrazine, dicamba, dicamba/diflufenzopyr plus Agral 90\% and $28 \%$ UAN, dicamba/atrazine, bromoxynil plus atrazine, prosulfuron plus dicamba and Agral 90, mesotrione plus atrazine and Agral 90, topramezone plus atrazine and Assist, tembotrione/thiencarbazone-methyl and glufosinate. Herbicide doses are listed in Table 3.

Table 1. Location, soil charactersitics, corn seeding and emergence dates, herbicide application dates and giant ragweed height and density for "Preplant tank-mixes" and "Postemergence tank-mixes" studies conducted in Ontario, Canada in 2013 and $2014^{\mathrm{a}}$.

\begin{tabular}{|c|c|c|c|c|c|c|c|c|c|c|c|}
\hline \multirow[b]{2}{*}{ Site } & \multirow[b]{2}{*}{ year } & \multirow[b]{2}{*}{ Location } & \multirow{2}{*}{$\begin{array}{c}\text { Soil } \\
\text { texture }\end{array}$} & \multirow[b]{2}{*}{ SOM } & \multirow[b]{2}{*}{$\mathrm{pH}$} & \multirow{2}{*}{$\begin{array}{l}\text { Seeding } \\
\text { date }\end{array}$} & \multirow[b]{2}{*}{ Emergence date } & \multirow{2}{*}{$\begin{array}{l}\text { PP application } \\
\text { date }\end{array}$} & \multirow{2}{*}{$\begin{array}{c}\text { POST } \\
\text { application } \\
\text { date }\end{array}$} & \multicolumn{2}{|c|}{ Giant ragweed } \\
\hline & & & & & & & & & & $\begin{array}{l}\text { Height } \\
\text { (cm) }\end{array}$ & $\begin{array}{c}\text { Density } \\
\left(\text { plants } \mathrm{m}^{-2}\right)\end{array}$ \\
\hline $\mathrm{S} 1$ & 2013 & Tilbury & Clay & 3.5 & 6.7 & May 25 & June 03 & May 08 & - & up to 7 & 322 \\
\hline $\mathrm{S} 1$ & 2013 & Tilbury & Clay & 3.5 & 6.7 & May 25 & June 03 & - & May 27 & up to 10 & 70 \\
\hline $\mathrm{S} 2$ & 2013 & Essex & Clay & 3.4 & 7.7 & May 23 & June 01 & May 16 & - & up to 6 & 34 \\
\hline $\mathrm{S} 2$ & 2013 & Essex & Clay & 3.4 & 7.7 & May 23 & June 01 & - & May 27 & up to 8 & 61 \\
\hline $\mathrm{S} 3$ & 2014 & Harrow & Loam & 3.2 & 7.4 & May 24 & May 30 & May 16 & - & up to 16 & 28 \\
\hline $\mathrm{S} 3$ & 2014 & Harrow & Loam & 3.2 & 7.4 & May 24 & May 30 & - & June 12 & up to 15 & 22 \\
\hline $\mathrm{S} 4$ & 2014 & Harrow & Clay & 3.2 & 7.6 & June 02 & June 11 & May 30 & - & up to 12 & 16 \\
\hline S4 & 2014 & Harrow & Clay & 3.2 & 7.6 & June 02 & June 11 & - & June 16 & up to 31 & 7.5 \\
\hline
\end{tabular}

${ }^{\mathrm{a}}$ Abbreviations: PP: prior to corn seeding; POST: after corn emergence.

Table 2. Visual estimates of glyphosate-resistant giant ragweed control 4 and 8 WAA and giant ragweed dry weight and density for herbicides tank-mixed with glyphosate applied prior to corn seeding from studies conducted in Ontario, Canada in 2013 and $2014^{\mathrm{ab}}$.

\begin{tabular}{|c|c|c|c|c|c|}
\hline \multirow{2}{*}{ Treatment } & \multirow{2}{*}{$\begin{array}{c}\text { Dose } \\
\mathrm{g} \cdot \mathrm{ae} \cdot \mathrm{ha}^{-1}\end{array}$} & \multicolumn{2}{|c|}{ Weed control (\%) } & \multirow{2}{*}{$\begin{array}{c}\text { Density } \\
\text { plants } \mathrm{m}^{-2}\end{array}$} & \multirow{2}{*}{$\begin{array}{c}\text { Dry weight } \\
\mathrm{g} \mathrm{m}^{-2}\end{array}$} \\
\hline & & 4 WAA & 8 WAA & & \\
\hline Weedy control & & $0 \mathrm{~d}$ & $0 \mathrm{e}$ & $16 \mathrm{~d}$ & $12.8 \mathrm{c}$ \\
\hline Weed free control & & $100 \mathrm{a}$ & $100 \mathrm{a}$ & $0 \mathrm{a}$ & $0.0 \mathrm{a}$ \\
\hline Glyphosate + atrazine & $1800+1500$ & $54 \mathrm{c}$ & $44 \mathrm{~cd}$ & $11 \mathrm{~cd}$ & $4.0 \mathrm{bc}$ \\
\hline Glyphosate + dicamba & $1800+600$ & $95 \mathrm{ab}$ & $94 \mathrm{~b}$ & $0 \mathrm{a}$ & $0.0 \mathrm{a}$ \\
\hline Glyphosate + dicamba/atrazine & $1800+1800$ & $91 \mathrm{~b}$ & $93 \mathrm{~b}$ & $1 \mathrm{a}$ & $0.1 \mathrm{a}$ \\
\hline Glyphosate + mesotrione + atrazine & $1800+140+1500$ & $94 \mathrm{a}$ & $95 \mathrm{ab}$ & $0 \mathrm{a}$ & $0.0 \mathrm{a}$ \\
\hline Glyphosate + flumetsulam & $1800+50$ & $40 \mathrm{c}$ & $26 \mathrm{~d}$ & $22 \mathrm{~d}$ & $8.9 \mathrm{c}$ \\
\hline Glyphosate + isoxaflutole + atrazine & $1800+105+1063$ & $84 \mathrm{~b}$ & $89 \mathrm{~b}$ & $4 \mathrm{bc}$ & $1.0 \mathrm{ab}$ \\
\hline Glyphosate + saflufenacil/dimethenamid-P & $1800+735$ & $91 \mathrm{~b}$ & $87 \mathrm{~b}$ & $1 \mathrm{ab}$ & $0.2 \mathrm{a}$ \\
\hline Glyphosate $+S$-metolachlor/atrazine & $1800+2880$ & $50 \mathrm{c}$ & $49 \mathrm{c}$ & $9 \mathrm{~cd}$ & $4.3 \mathrm{bc}$ \\
\hline Glyphosate + rimsulfuron & $1800+15$ & $91 \mathrm{~b}$ & $93 \mathrm{~b}$ & $1 \mathrm{ab}$ & $0.1 \mathrm{a}$ \\
\hline
\end{tabular}

${ }^{\mathrm{a}}$ Abbreviation: WAA, weeks after herbicide application; ${ }^{\mathrm{b}}$ Means followed by the same letter (a - e) within a column do not significantly differ according to Fisher's Protected LSD at $\mathrm{P}<0.05$. 
Table 3. Visual estimates of glyphosate-resistant giant ragweed control 4 and 8 WAA and giant ragweed dry weight and density for postemergence herbicides applied after corn emergence from studies conducted in Ontario, Canada in 2013 and $2014^{\mathrm{ab}}$.

\begin{tabular}{|c|c|c|c|c|c|}
\hline \multirow{2}{*}{ Treatment } & \multirow{2}{*}{$\begin{array}{c}\text { Dose } \\
\mathrm{g} \cdot \mathrm{ae} / \mathrm{ai} \cdot \mathrm{ha}^{-1}\end{array}$} & \multicolumn{2}{|c|}{ Weed control $(\%)$} & \multirow{2}{*}{$\begin{array}{c}\text { Density } \\
\text { plants } \mathrm{m}^{-2}\end{array}$} & \multirow{2}{*}{$\begin{array}{c}\text { Dry weight } \\
\mathrm{g} \mathrm{m}^{-2}\end{array}$} \\
\hline & & 4WAA & 8WAA & & \\
\hline Weedy control & & $0 \mathrm{~g}$ & $0 \mathrm{~h}$ & $15 \mathrm{f}$ & $84.4 \mathrm{~g}$ \\
\hline Weed free control & & $100 \mathrm{a}$ & $100 \mathrm{a}$ & $0 \mathrm{a}$ & $0.0 \mathrm{a}$ \\
\hline Glyphosate & 900 & $24 \mathrm{f}$ & $31 \mathrm{~g}$ & $16 \mathrm{f}$ & $37.9 \mathrm{fg}$ \\
\hline Glyphosate $+2,4-\mathrm{D}$ ester & $900+560$ & $75 \mathrm{~b}$ & 84 bcd & $1 \mathrm{ab}$ & $0.7 \mathrm{abc}$ \\
\hline Glyphosate + atrazine & $900+1000$ & $27 \mathrm{ef}$ & $39 \mathrm{fg}$ & 10 ef & 23.9 efg \\
\hline Glyphosate + dicamba & $900+600$ & $80 \mathrm{~b}$ & $94 \mathrm{ab}$ & $1 \mathrm{ab}$ & $0.5 \mathrm{ab}$ \\
\hline Glyphosate + dicamba/diflufenzopyr ${ }^{\text {cd }}$ & $900+200$ & $75 \mathrm{~b}$ & $89 \mathrm{bc}$ & $2 \mathrm{abc}$ & $0.7 \mathrm{abc}$ \\
\hline Glyphosate + dicamba/atrazine & $900+1500$ & $72 \mathrm{bc}$ & $86 \mathrm{bc}$ & $2 a b c$ & $1.8 \mathrm{abcd}$ \\
\hline Glyphosate + bromoxynil +atrazine & $900+280+1500$ & $62 \mathrm{bcd}$ & 83 bcd & $2 \mathrm{abc}$ & $3.3 \mathrm{abcd}$ \\
\hline Glyphosate + prosulfuron + dicamba $^{\mathrm{c}}$ & $900+10+140$ & $51 \mathrm{~d}$ & 78 bcde & $3 \mathrm{bc}$ & $3.6 \mathrm{abcd}$ \\
\hline Glyphosate + mesotrione + atrazine $^{c}$ & $900+100+280$ & $54 \mathrm{~cd}$ & 72 cde & $3 \mathrm{bcd}$ & 5.5 cde \\
\hline Glyphosate + topramezone + atrazine $^{\mathrm{e}}$ & $900+13+500$ & 42 def & $43 \mathrm{fg}$ & $7 \mathrm{def}$ & $9.6 \mathrm{def}$ \\
\hline Glyphosate +tembotrione/thiencarbazone-methyl & $900+45$ & 46 de & $63 \mathrm{def}$ & $7 \mathrm{def}$ & $8.0 \mathrm{de}$ \\
\hline Glyphosate + glufosinate & $900+500$ & $45 \mathrm{de}$ & 58 ef & 4 cde & $4.6 \mathrm{bcd}$ \\
\hline
\end{tabular}

${ }^{a}$ Abbreviations: WAA, weeks after herbicide application; ${ }^{b}$ Means followed by the same letter within a column (a - g) do not significantly differ according to Fisher's Protected LSD at P < 0.05; ${ }^{\mathrm{c}}$ Added Agral 90 ( $\left.0.25 \% \mathrm{vol} / \mathrm{vol}\right) ;{ }^{\mathrm{d}}$ Added $28 \%$ UAN $(2.5 \% \mathrm{vol} / \mathrm{vol}) ;{ }^{\mathrm{e}}$ Added Assist $(1.25 \mathrm{vol} / \mathrm{vol})$.

\subsection{Data Collection}

Giant ragweed control was estimated visually on a scale of $0 \%$ (no control) to $100 \%$ (complete plant death) at four and eight weeks after application (WAA). Corn injury was also documented on these dates (data not shown). Injury ratings were recorded on a scale of $0 \%$ to $100 \%$, with $0 \%$ defined as no corn injury and $100 \%$ as complete corn death. Giant ragweed density and dry weight were determined at 8 WAA by counting and then cutting the plants at the soil surface from two $0.25 \mathrm{~m}^{2}$ quadrats per plot. Plants were then dried at $60^{\circ} \mathrm{C}$ to constant moisture and weighed.

\subsection{Statistical Analysis}

Data were analyzed using PROC MIXED in SAS (SAS Institute Inc., Cary, NC, Version 9.3). Herbicide treatment was considered a fixed effect, while environment (year-location combinations), the interaction between environment and herbicide treatment, and replicate nested within environment were considered random effects. Significance of the fixed effect was determined using the F-test; random effects were tested using a Z-test of the variance estimate. Data was tested for normality and homogeneity of variance using PROC UNIVARIATE; normality was determined using the Shapiro-Wilkes test in addition to the normal probability plot. For all weed control ratings, the weedy control (assigned a value of zero) was excluded from the analysis. However, injury and weed control assessments were independently compared to the weedy and weed-free controls, respectively. To satisfy the assumptions of the variance analyses, weed control was arcsine-transformed; giant ragweed density and dry weight were log-transformed. Treatment means were separated using Fisher's Protected LSD at a level of $\mathrm{P}<0.05$. Data compared on the transformed scale were converted back to the original scale for presentation of results.

\section{Results and Discussion}

For PP and POST tank-mix experiments no significant treatment by environment interaction was present, therefore all environments were combined for further analysis. Corn injury attributed to PP tank-mixes was generally below 10\% for environments S1 and S2, while S3 and S4 presented 0\% injury 4 WAA (Table 1). For POST tank-mix treatments, injury was likewise restricted to environments S1 and S2. However, injury was transient decreasing from $10 \%$ or less 1 WAA, to fewer than $5 \%$ by 4 WAA. 


\subsection{Preplant Tank-Mixes}

Glyphosate tank-mixes, applied PP, containing dicamba or mesotrione plus atrazine provided the greatest control of GR giant ragweed ( $94 \%$ to $95 \%$ ) and were statistically equivalent to the weed-free control (Table 2). Similarly, excellent control of GR giant ragweed was observed for treatments containing dicamba/atrazine, isoxaflutole plus atrazine, saflufenacil/dimethenamid-P and rimsulfuron which provided $91 \%$ to $93 \%, 84 \%$ to $89 \%$, $87 \%$ to $91 \%$ and $91 \%$ to $93 \%$ control, respectively. In contrast, glyphosate plus atrazine, flumetsulam or $S$-metolachlor/atrazine applied PP provided unacceptable control ranging from $26 \%$ to $54 \%$. GR giant ragweed control was similar at 4 and 8 WAA with the exceptions of atrazine and flumetsulam for which control decreased by $10 \%$ and $14 \%$, respectively.

Dicamba, dicamba/atrazine, mesotrione plus atrazine, isoxaflutole plus atrazine, saflufenacil/dimethenamid-P, and rimsulfuron tank-mixes reduced GR giant ragweed density by $100 \%, 94 \%, 100 \%, 75 \%, 94 \%$ and $94 \%$, respectively (Table 2). In contrast, glyphosate plus atrazine, flumetsulam and $S$-metolachlor/atrazine reduced GR giant ragweed density $31 \%, 38 \%$ and $44 \%$, respectively. GR giant ragweed dry weight was reduced by $100 \%$, $99 \%, 100 \%, 92 \%, 98 \%$ and $99 \%$ with glyphosate plus dicamba, dicamba/atrazine, mesotrione plus atrazine, isoxaflutole plus atrazine, saflufenacil/dimethenamid-P and rimsulfuron, respectively; whereas glyphosate plus atrazine, flumetsulam and $S$-metolachlor/atrazine reduced density only by $69 \%, 30 \%$ and $66 \%$, respectively.

In other studies, poor GR giant ragweed control with glyphosate plus flumetsulam, applied PP, has been reported ranging from $12 \%$ to $66 \%$ [13] and $26 \%$ to $61 \%$ [14], 8 WAA. Reference [17] similarly reported unacceptable giant ragweed control of 9 to $52 \% 8$ WAA with atrazine applied PP in corn. While the current study demonstrated good control for glyphosate plus mesotrione and atrazine applied PP, reference [18] reported only GR giant ragweed suppression from the same treatment. Furthermore, reference [17] reported moderate, yet variable, control of giant ragweed ranging from $33 \%$ to $80 \%$ from mesotrione plus atrazine. In dicamba-tolerant soybean, up to $100 \%$ control of GR giant ragweed 8 WAA has been reported from dicamba PP application [19]. On the contrary, reference [20] reported poor control (30\%) of GR giant ragweed with dicamba applied PP in dicamba-tolerant soybeans, however, control increased to over $80 \%$ when accompanied by a dicamba POST application. Moreover, reference [12] reported that either single or sequential dicamba applications, when timed to appropriately match the biology of the weed species, can be used as an effective integrated weed management tool for the control of GR giant ragweed.

\subsection{Postemergence Tank-Mixes}

At 4 WAA, none of the glyphosate POST tank-mixes provided acceptable control (24\% to $80 \%)$ of GR giant ragweed (Table 3). Among the POST tank-mixes evaluated, glyphosate tank-mixed with 2,4-D ester, dicamba, dicamba/diflufenzopyr and dicamba/atrazine were most effective and provided $75 \%, 80 \%, 75 \%$ and $72 \%$ control of GR giant ragweed, respectively. While the remaining herbicides performed poorly, treatment with glyphosate alone and tank-mixed with atrazine and topramezone plus atrazine were least effective providing only $24 \%, 27 \%$ and $42 \%$ control, respectively.

In general, GR giant ragweed control was greater at 8 WAA than 4 WAA for the POST tank-mixes evaluated (Table 3). Glyphosate plus dicamba (94\%) provided the best control of GR giant ragweed; control was equivalent to the weed-free control. Tank-mixes of glyphosate plus 2,4-D ester, dicamba/diflufenzopyr, dicamba/atrazine, bromoxynil plus atrazine and prosulfuron plus dicamba provided $84 \%, 89 \%, 86 \%, 83 \%$ and $78 \%$ control, respectively and were statistically equal to the best tank-mix, glyphosate plus dicamba. Although control increased by 8 WAA, the resultant level of control would not generally be considered commercially acceptable by a grower, with the exception of glyphosate plus dicamba.

Glyphosate plus dicamba, applied POST, reduced GR giant ragweed density 93\% (Table 3). Similarly, glyphosate plus 2,4-D ester, dicamba/diflufenzopyr, dicamba/atrazineand bromoxynil plus atrazine reduced GR giant ragweed density by $93 \%, 87 \%, 87 \%$ and $87 \%$, respectively. Glyphosate plus prosulfuron plus dicamba, mesotrione plus atrazine and glufosinate provided a moderate reduction in GR giant ragweed density ( $73 \%$ to $80 \%$ ), while treatments containing glyphosate alone and glyphosate tank-mixed with atrazine, topramezone plus atrazine and tembotrione/thiencarbazone-methyl caused an unacceptable reduction in GR giant ragweed density ( $0 \%$ to $53 \%$ ).

Glyphosate plus 2,4-D ester, dicamba, dicamba/diflufenzopyr, dicamba/atrazine, bromoxynil plus atrazine and prosulfuron plus dicamba reduced GR giant ragweed dry weight by $99 \%, 99 \%, 99 \%, 98 \%, 96 \%$ and $96 \%$, re- 
spectively and were found to be equal to the weed-free control. Although glyphosate tank-mixed with mesotrione plus atrazine, topramezone plus atrazine, tembotrione/thiencarbazone-methyl and glufosinate provided poor control and density reduction, the reduction in density relative to the weedy control was moderate ranging from $89 \%$ to $95 \%$. Glyphosate applied alone and in tank-mix with atrazine reduced GR giant ragweed dry weight by $55 \%$ and $72 \%$ respectively.

In other studies, reference [17] evaluated control of giant ragweed using various POST herbicides in corn and found dicamba/atrazine most effective, ranging from $87 \%$ to $94 \%$, while atrazine control was as low as $46 \%$. In dicamba-tolerant soybean, up to $100 \%$ control of GR giant ragweed has been reported for dicamba applied POST [19] and for sequential early- and late-POST dicamba applications [20]. Up to 90\% control of GR giant ragweed has been reported for glufosinate under greenhouse conditions [21]; however, any obstructing vegetation that may be present under field conditions has the potential to decrease control as glufosinate is a contact herbicide and lacks in-plant mobility.

\section{Conclusion}

In summary, greater control of GR giant ragweed in corn was generally obtained by herbicide tank-mixes applied PP compared with tank-mixes applied POST. Glyphosate plus dicamba or mesotrione plus atrazine and applied PP were the most efficacious and provided $94 \%$ to $95 \%$ control of GR giant ragweed, whereas atrazine, flumetsulam and $S$-metolachlor/atrazine tank-mixes were the least effective at $26 \%$ to $54 \%$ control. For POST herbicide application timing, glyphosate plus 2,4-D, dicamba-based herbicides and bromoxynil plus atrazine provided the best control (83\% to $94 \%)$, while glyphosate alone and tank-mixed with atrazine and topramezone plus atrazine provided the poorest control (24\% to $43 \%)$. Given giant ragweed's pattern of early and prolonged emergence and ability to depress yield [2] [6], it is most advantageous to manage infestations early in the growing season when plants are smallest [13]. It is recommended that future research should evaluate season-long control of GR giant ragweed using sequential herbicide applications to minimize yield losses in corn incurred from this competitive annual broadleaf weed.

\section{Acknowledgements}

The authors would like to acknowledge the technical assistance of Chris Kramer and Jonathan Brinkman. Funding for this project was provided by Grain Farmers of Ontario and Agricultural Adaptation Council.

\section{References}

[1] Abul-Fatih, H.A. and Bazzaz, F.A. (1979) The Biology of Ambrosia trifida L. II. Germination, Emergence, Growth, and Survival. The New Phytologist, 83, 817-827. http://dx.doi.org/10.1111/j.1469-8137.1979.tb02312.x

[2] Bassett, I.J. and Crompton, C.W. (1982) The Biology of Canadian Weeds: 55: Ambrosia trifida L. Canadian Journal of Plant Science, 62, 1000-1010.

[3] Johnson, B., et al. (2007) Biology and Management of Giant Ragweed. https://www.extension.purdue.edu/extmedia/BP/GWC-12.pdf

[4] Abul-Faith, H.A. (1979) The Biology of Ambrosia trifida L. III. Growth and Biomass Allocation. The New Phytologist, 83, 829-838. http://dx.doi.org/10.1111/j.1469-8137.1979.tb02314.x

[5] Baysinger, J.A. and Sims, B.D. (1991) Giant Ragweed (Ambrosia trifida) Interference in Soybeans (Glycine max). Weed Science, 39, 358-362.

[6] Harrison, S.K., Regnier, E.E., Schmoll, J.T. and Webb, J.E. (2001) Competition and Fecundity of Giant Ragweed in Corn. Weed Science, 49, 224-229. http://dx.doi.org/10.1614/0043-1745(2001)049[0224:CAFOGR]2.0.CO;2

[7] Ontario Ministry of Agriculture, Food, and Rural Affairs (2003) Ontario Weeds: Giant Ragweed. http://www.omafra.gov.on.ca/english/crops/facts/ontweeds/giant_ragweed.htm

[8] Barrett, S.C.H. (1982) Genetic Variation in Weeds. In: Charudattan, R.C. and Walker, H.L., Eds., Biological Control of Weeds with Plant Pathogens, John Wiley, New York, 73-98.

[9] Sikkema, P.H., et al. (2009) Suspected Glyphosate-Resistant Giant Ragweed in Ontario. Proceedings of the 64th Annual Meeting of the NCWSS, Champaign, December 2009, 167.

[10] Vink, J.P., et al. (2012) Occurrence and Distribution of Glyphosate-Resistant Giant Ragweed (Ambrosia trifida L.) in Southwestern Ontario. Canadian Journal of Plant Science, 92, 533-539. http://dx.doi.org/10.4141/cjps2011-249 
[11] Follings, J., Soltani, N., Robinson, D.E., Tardif, F.J., Lawton, M.B. and Sikkema, P.H. (2013) Distribution of Glyphosate and Cloransulam-Methyl Resistant Giant Ragweed (Ambrosia trifida L.) Populations in Southern Ontario. Agricultural Sciences, 4, 570-576. http://dx.doi.org/10.4236/as.2013.410077

[12] Spaunhorst, D.J., Siefert-Higgins, S. and Bradley, K.W. (2014) Glyphosate-Resistant Giant Ragweed (Ambrosia trifida) and Waterhemp (Amaranthus rudis) Management in Dicamba-Resistant Soybean (Glycine max). Weed Technology, 28, 131-141. http://dx.doi.org/10.1614/WT-D-13-00091.1

[13] Follings, J., Soltani, N., Robinson, D.E., Tardif, F.J., Lawton, M.B. and Sikkema, P.H. (2013) Control of Glyphosate Resistant Giant Ragweed in Soybean with Preplant Herbicides. Agricultural Sciences, 4, 195-205. http://dx.doi.org/10.4236/as.2013.44028

[14] Vink, J.P., Soltani, N., Robinson, D.E., Tardif, F.J., Lawton, M.B. and Sikkema, P.H. (2012) Glyphosate-Resistant Giant Ragweed (Ambrosia trifida L.) Control with Preplant Herbicides in Soybean [Glycine max (L.) Merr.]. Canadian Journal of Plant Science, 92, 913-922. http://dx.doi.org/10.4141/cjps2012-025

[15] Brabham, C.B., Johnson, W.G., Loux, M.M. and Dobbels, T. (2011) Control of Glyphosate-Resistant and GlyphosateSensitive Giant Ragweed in Soybean with Adjuvant, Fomesafen, and Glyphosate Tank Mixtures. Crop Management, 10, 1 .

[16] Jhala, A.J., Sandell, L.D. and Kruger, G.R. (2014) Control of Glyphosate-Resistant Giant Ragweed (Ambrosia trifida L.) with 2,4-D Followed by Pre-Emergence or Post-Emergence Herbicides in Glyphosate-Resistant Soybean (Glycine max L.). American Journal of Plant Science, 15, 2289-2297. http://dx.doi.org/10.4236/ajps.2014.515243

[17] Soltani, N., Shropshire, C. and Sikkema, P. (2011) Giant Ragweed (Ambrosia trifida L.) Control in Corn. Canadian Journal of Plant Science, 91, 577-581. http://dx.doi.org/10.4141/cjps2010-004

[18] Bollman, S.L., Kells, J.J., Bauman, T.T., Loux, M.M., Slack, C.H. and Sprague, C.L. (2006) Mesotrione and Atrazine Combinations Applied Preemergence in Corn (Zea mays L.). Weed Technology, 20, 908-920. http://dx.doi.org/10.1614/WT-04-285.1

[19] Vink, J.P., Soltani, N., Robinson, D.E., Tardif, F.J., Lawton, M.B. and Sikkema, P.H. (2012) Glyphosate-Resistant Giant Ragweed (Ambrosia trifida) Control in Dicamba-Tolerant Soybean. Weed Technology, 26, 422-428. http://dx.doi.org/10.1614/WT-D-11-00184.1

[20] Johnson, B., et al. (2010) Weed Control in Dicamba-Resistant Soybeans. Crop Management, 9.

[21] Norsworthy, J.K., Jha, P., Steckel, L.E. and Scott, R.C. (2010) Confirmation and Control of Glyphosate-Resistant Giant Ragweed (Ambrosia trifida) in Tennessee. Weed Technology, 24, 64-70. http://dx.doi.org/10.1614/WT-D-09-00019.1 
Scientific Research Publishing (SCIRP) is one of the largest Open Access journal publishers. It is currently publishing more than 200 open access, online, peer-reviewed journals covering a wide range of academic disciplines. SCIRP serves the worldwide academic communities and contributes to the progress and application of science with its publication.

Other selected journals from SCIRP are listed as below. Submit your manuscript to us via either submit@scirp.org or Online Submission Portal.
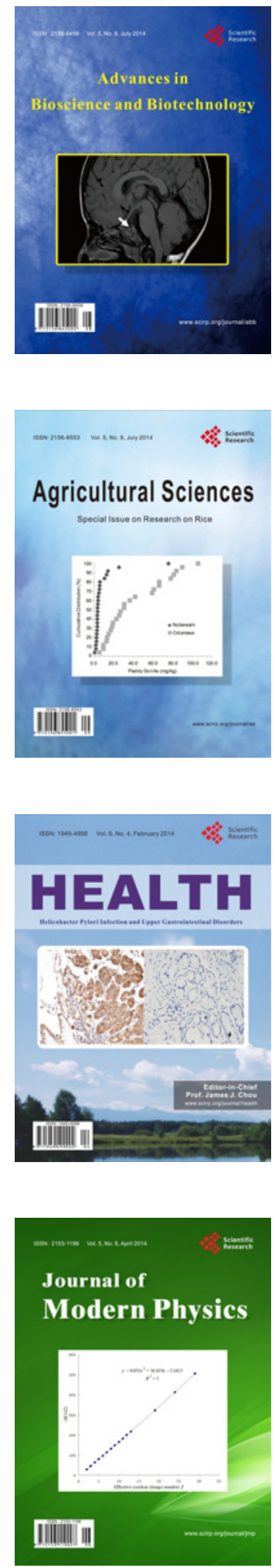
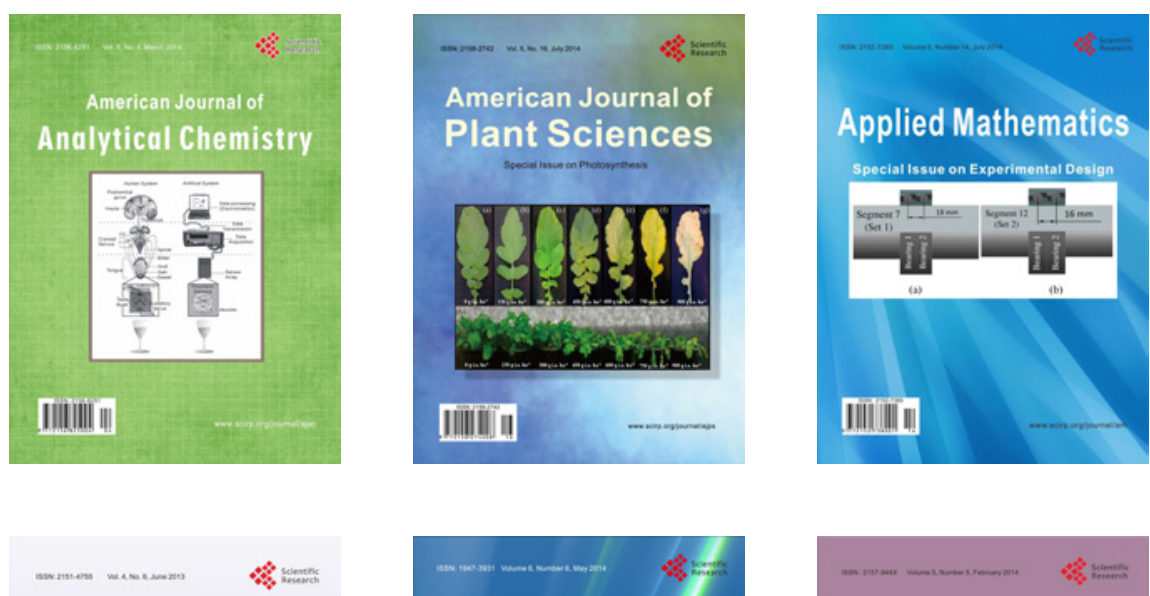

Creative Education
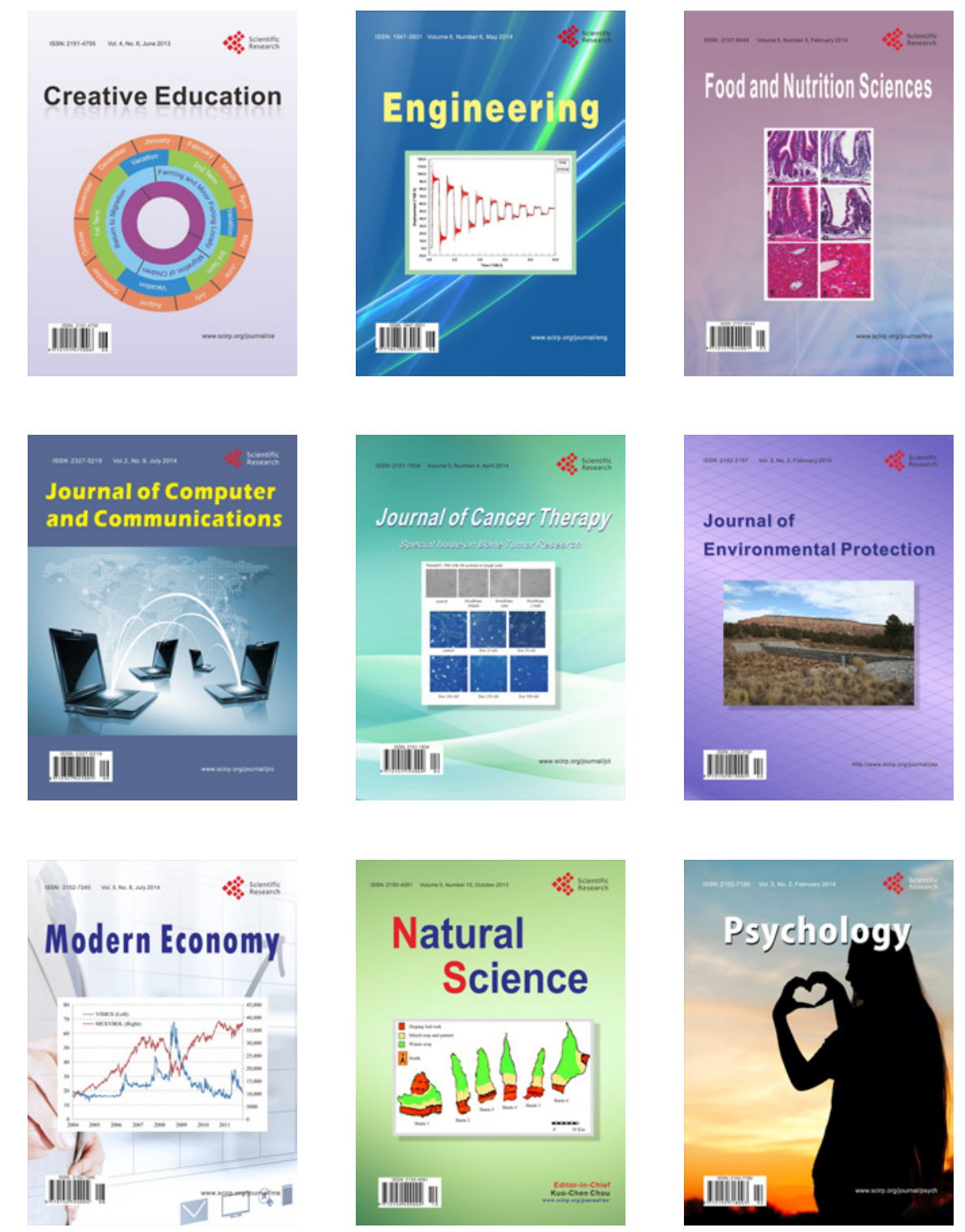